\title{
PENGARUH PENERAPAN METODE KOMIDI PUTAR DISKUSI TERHADAP MINAT BELAJAR IPA SISWA SDN
}

\author{
Nurhayati Selvi \\ Dosen PGSD Universitas Islam Makassar \\ e-mail: nurhayatiselvi778@gmail.com
}

\begin{abstract}
This study aims to (1) know the description of implementation methods carousel discussion; (2) know the description of interest in learning science before and after the discussion carousel method; (3) the effect of the application of methods carousel discussion towards interest in learning science. Methods used Tru Experiment Design with design pretestpossttest control group design. The technique of collecting data through questionnaires interest, observation and interviews. Its population is a whole class of elementary school SDN KIP Maccini Makassar 2014-2015 school year as many as 66 people. Mechanical Sampling was stratified random sampling, obtained as many as 56 people. Data analysis technique used is descriptive and inferential analysis. The results showed that the application of the carousel discussion method comprising the step of grouping students, forming two concentric circles, conversations and conclusions are generally performing well. Siwa learning interest in learning science before implementation of the method carousel discussion is in the category of low and medium, the experimental group or the control group. There is increasing interest in students in the high category in the experimental group after a given method carousel discussion while the control group the medium category. Use of the method carousel discussion affect the interest to learn science.
\end{abstract}

Key words: Discussion Carrousel Method, Learning Interest, Science Learning

\begin{abstract}
ABSTRAK
Penelitian ini bertujuan untuk (1) Mengetahui gambaran pelaksanaan metode diskusi komidi putar; (2) Mengetahui gambaran minat belajar ilmu sebelum dan setelah metode diskusi komidi putar; (3) pengaruh penerapan diskusi metode komidi putar terhadap minat belajar sains. Metode yang digunakan Tru Desain Eksperimen dengan desain kelompok kontrol desain pretest-possttest. Teknik pengumpulan data melalui kuesioner, observasi dan wawancara. Populasinya adalah seluruh kelas SD SDN KIP Maccini Makassar 2014-2015 tahun ajaran sebanyak 66 orang. Teknik Pengambilan sampel stratified random sampling, sebanyak 56 orang.. Hasil penelitian menunjukkan bahwa penerapan metode diskusi komidi putar terdiri dari tahap pengelompokan siswa, membentuk dua lingkaran konsentris, percakapan dan kesimpulan umumnya berkinerja baik. Siswa belajar minat belajar ilmu sebelum pelaksanaan diskusi metode komidi putar adalah dalam kategori, kelompok eksperimen rendah dan menengah atau kelompok kontrol. Ada peningkatan minat siswa dalam kategori tinggi pada kelompok eksperimen setelah diberikan metode diskusi komidi putar sedangkan kelompok kontrol kategori sedang. Penggunaan metode diskusi komidi putar mempengaruhi minat untuk belajar ilmu.
\end{abstract}

Kata kunci: Diskusi komidi putar, minat belajar 


\section{PENDAHULUAN}

Dalam lingkup pendidikan terdapat proses belajar mengajar yang dapat berpengaruh kepada sikap dan kemampuan intelektual anak. Dalam cakupan ini salah satu mata pelajaran yang dapat membantu anak mengembangkan sikap ilmiah adalah pembelajaran IPA SD. Menurut Suwarno et al., (2009) IPA berupaya agar siswa mau meningkatkan kecerdasan dan pemahamannya tentang alam seisinya yang penuh dengan rahasia yang tidak ada habishabisnya.

Prestasi belajar siswa khususnya pada mata pelajaran IPA dewasa ini sangat perlu perhatian. Berdasarkan data yang diperoleh dari survey international Trends in International Mathematics and Science (TIMSS), diketahui rata-rata hasil prestasi sains Indonesia tingkat Internasional yaitu pada tahun 1999 Indonesia berada pada urutan 32 dari 38 negara, pada tahun 2003 berada pada peringkat 37 dari 46 negara dan pada tahun 2007 berada di peringkat 35 dari 49 negara (Kemdikbud, 2011).

Dari data tersebut terlihat rendahnya prestasi IPA pada tingkat Internasional. Rendahnya prestasi di Indonesia mempengaruhi kualitas pendidikan. Jika hal tersebut dibiarkan dan tidak ada upaya memperbaikinya, maka dapat mangakibatkan semakin buruknya kualitas pendidikan khsususnya pada Mata pelajaran IPA di masa depan.

Dari hasil wawancara yang dilakukan dengan guru kelas SDN KIP Maccini ditemukan data hasil belajar IPA pada tahun ajaran 2014/2015 hanya sekitar 59\% siswa kelas V yang memenuhi standar Kriteria Ketuntasan Minimal (KKM) yaitu 70, maka di kategorikan berada di bawah standar ketuntasan yang diharapkan.

Beberapa alasan hasil belajar IPA rendah yaitu faktor dari dalam diri siswa misalnya tidak adanya ketertarikan siswa mengikuti pembelajaran. Sedangkan faktor dari luar siswa misalnya metode yang digunakan guru dalam kagiatan pembelajaran kurang menarik, sehingga menimbulkan rasa bosan terhadap siswa. Kondisi ini tentunya mengakibatkan hasil belajar siswa menjadi rendah.

Menurut Decroly (dalam Tirtarahardja 2010) dari penyelidikan psikologi, menetapkan bahwa anak-anak mempunyai minat yang spontan (sewajarnya). Minat-minat spontan itu dapat dibedakan menjadi minat terhadap diri sendiri yang meliputi dorongan mempertahankan diri, mencari makan dan minum, memelihara diri sedangkan minat terhadap masyarakat meliputi dorongan sibuk bermain-main meniru orang lain. Pendidikan dan pengajaran harus selalu dihubungkan dengan pusat-pusat minat tersebut. Salah satu cara mewujudkan hal tersebut dengan menerapkan metode yang interaktif seperti metode komidi putar diskusi.

Metode komidi putar diskusi ini bertujuan mencapai aktifitas berfikir, kecerdasan emosional, kemandirian, saling ketergantungan, multi sensasi, menyenangkan, dan artikulasi. Elemen yang terdapat dalam metode ini yaitu kerja individu, kerja kelompok, bergerak, berbicara, dan mendengarkan. Elemen-elemen tersebut memancing daya tarik siswa untuk mengikuti pelajaran, tentunya minat siswa dalam belajar terpelihara.

Menurut Ginnis (2008) Beberapa cara yang dapat diberikan kepada siswa dalam menarik minat belajarnya, yaitu: berikan kesegaran dan variasi untuk mempertahankan perhatiannya; pahamilah kesenangan murid; berikan gambaran ke arah mana materi yang akan dipelajari. Metode komidi putar sangat cocok diterapkan dalam pembelajaran IPA karena muatan dari metode tersebut mengkolaborasikan diskusi dengan bermain. Maka di harapkan penggunaan metode ini dapat memberikan konstribusi yang baik di dalam prestasi belajar IPA.

Berdasarkan uraian tersebut, peneliti ingin mengetahui kebenaran tentang "Pengaruh penerapan metode komidi putar diskusi terhadap minat belajar IPA siswa kelas V SDN KIP Maccini Makassar".

Berdasarkan latar belakang diatas maka yang menjadi rumusan masalah dalam penelitian ini adalah: (1) Bagaimanakah gambaran penerapan metode komidi putar diskusi di kelas V SDN KIP Maccini Makassar?; (2) Bagaimanakah gambaran minat belajar IPA siswa kelas V SDN KIP Maccini sebelum dan sesudah diberikan metode komidi putar diskusi?; (3) Apakah ada pengaruh penerapan metode komidi putar diskusi terhadap minat belajar IPA di SDN KIP Maccini Makassar?

Menurut Ginnis (2008) Metode Komidi Putar Diskusi adalah pembelajaran dengan menggunakan konsep komedi putar, dimana siswa duduk saling berhadapan dengan bentuk 
melingkar, kemudian guru menyampaikan atau memperdengarkan topik materi. Setelah itu, siswa yang duduk saling berhadapan diberi waktu yang telah ditentukan untuk menceritakan kembali isi materi kepada pasangan yang dihadapinya. Metode ini dapat membantu siswa merumuskan opini mereka tentang materi pembelajaran. Minat belajar siswa yang tinggi memudahkan siswa dalam pencapaian tujuan belajar. Menurut Slameto (2010), siswa yang berminat dalam belajar mempunyai ciri-ciri sebagai berikut: (a) Memperhatikan sesuatu yang dipelajari secara terus menerus. (b) Berpartisipasi aktif dalam suatu aktivitas atau kegiatan. (c) Ada perasaan senang atau ketertarikan terhadap sesuatu yang diminati. (d) Memperoleh suatu kebanggaan dan kepuasan pada sesuatu yang diminati. (e) Lebih menyukai pada suatu hal yang menjadi minatnya daripada hal yang lain.

Menurut Sardiman (2011), minat adalah suatu kondisi yang terjadi apabila seseorang melihat cirri-ciri atau arti sementara situasi yang dihubungkan dengan keinginan-keinginan atau kebutuhan-kebutuhan sendiri. Sejalan dengan pengertian tersebut menurut Djaali (2011)

Minat adalah rasa lebih suka dan rasa ketertarikan pada suatu hal atau aktifitas, tanpa ada yang menyuruh. Minat pada dasarnya adalah penerimaan akan suatu hubungan antara diri sendiri dengan sesuatu di luar diri. Semakin kuat atau dekat hubungan tersebut, semakin besar minatnya.

Hai ini sejalan dengan teori Pakem yang dikemukakan oleh Slameto (2010) yang mengatakan bahwa:

Suatu minat dapat diekspresikan melalui suatu pernyataan yang menunjukkan bahwa siswa lebih menyukai suatu hal dari pada hal lainnya, dapat pula dimanifestasikan melalui partisipasi dalam suatu aktifitas. Siswa memiliki minat terhadap suatu subyek tertentu akan cenderung untuk memberikan perhatian yang lebih besar terhadap subyek tertentu

Berdasarkan ciri-ciri minat yang dikemukakan Slameto (2010) maka dirumuskan indikator minat ada empat, yaitu perasaan senang, ketertarikan siswa, perhatian siswa.

R. Gagne (dalam Susanto, 2012) menyatakan bahwa Belajar dapat didefinisikan sebagai suatu proses di mana suatu organisme berubah perilakunya sebagai akibat pengalaman. Belajar dan mengajar merupakan dua konsep yang tidak dapat dipisahkan sama dengan yang lain. Dua konsep ini menjadi terpadu dalam satu kegiatan dimana terjadi interaksi antara guru dengan siswa, serta siswa dengan siswa pada saat pembelajaran berlangsung. Slameto (dalam Djamarah, 2011) mengemukakan bahwa belajar adalah suatu proses usaha yang dilakukan individu untuk memperoleh suatu perubahan tingkah laku yang baru secara keseluruhan, sebagai hasil pengalaman individu itu sendiri dalam interaksi dengan lingkungannya.

Menurut Darmojo (dalam Samatowa, 2011) menyatakan bahwa Ilmu Pengetahuan Alam atau Sains adalah pengetahuan yang rasional dan obyektif tentang alam semesta dengan segala isinya. Selain itu Nash (dalam Samatowa, 2011) menyatakan bahwa Sains itu adalah suatu cara atau metode untuk mengamati alam. Nash juga menjelaskan bahwa cara sains mengamati dunia bersifat analisis, lengkap, cermat serta menghubungkan antara satu fenomena dengan fenomena lain, sehingga keseluruhannya membentuk suatu prespektif yang baru tentang objek yang diamatinya.

Pada prinsipnya tujuan yang ingin dicapai di dalam penelitian ini adalah untuk mengetahui: (1) Gambaran penerapan metode komidi putar diskusi di kelas V SDN KIP Maccini Makassar; (2) Gambaran minat belajar IPA siswa kelas V SDN KIP Maccini sebelum dan sesudah diberikan metode komidi putar diskusi; (3) Pengaruh penerapan metode komidi putar diskusi terhadap minat belajar IPA di SDN KIP Maccini Makassar.

Hipotesis penelitian ini adalah: Pengaruh penggunaan metode komidi putar diskusi terhadap minat belajar IPA siswa kelas V SDN KIP Maccini Makassar.

\section{METODE}

Jenis penilitian ini adalah penelitian eksperimen, menggunakan true eksperimental design dengan rancangan penelitian pretest-posst test control group design yang bertujuan untuk mengetahui pengaruh Penerapan Metode Komidi Putar Diskusi terhadap Minat Belajar 
IPA Siswa Kelas V SD. Definisi operasional variabel sebagai berikut: (1) Penerapan Metode komidi putar diskusi pemberlakuan pembelajaran dengan menggunakan konsep komedi putar namun proses pembelajarannya menggunakan metode diskusi antar kelompok, adapun langkahlangkah penerapannya yaitu pengelompokan siswa, membentuk 2 lingkaran konsentris, percakapan dua kelompok, dan membuat kesimpulan. (2) Minat belajar IPA adalah dorongan dalam diri/respon seseorang yang ditunjukkan dengan ketertarikan memperhatikan dan mengikuti proses belajar mengajar sehingga dapat terlibat secara langsung dalam proses pembelajaran. Adapun indikatornya yaitu perasaan Senang, ketertarikan siswa, perhatian siswa dan keterlibatan siswa. Minat belajar IPA disini akan diukur menggunakan skala likert, dimana skor 5 untuk sangat setuju, 4 untuk setuju, 3 untuk ragu-ragu, 2 untuk tidak setuju, dan 1 untuk sangat tidak setuju. Populasi dalam penelitian ini adalah seluruh siswa kelas V SDN KIP Maccini Makassar semester genap tahun ajaran 2014/2015 yang berjumlah 66 orang siswa, dengan jumlah siswa laki-laki sebanyak 35 orang dan jumlah siswa perempuan sebanyak 31 orang. Peneliti menentukan jumlah sampel untuk masing-masing kelompok adalah 28 siswa dari 66 total populasi. Sampel dalam penelitian ini diambil secara acak dengan menggunakan sampling acak berlapis (Supranto (1992) dengan pertimbangan jumlah perempuan dan laki-laki tidak sama banyak, sehingga populasi dipecah sedemikian rupa sehingga setiap stratum homogin.

Teknik pengumpulan data dan instrument penelitian yang digunakan dalam penelitian ini yaitu kuesioner minat belajar IPA, observasi, wawancara. Pengisian lembar angket dilakukan sebanyak dua kali, yaitu pre-test dan post-test. Instrumen pengukuran yang digunakan dalam penelitian ini telah divalidasi meliputi Validasi rasional dan Validasi Empiris. Uji coba kuesioner minat belajar IPA dilakukan terhadap 20 anak di SDI Darul Hikmah Kecamatan Makassar Kota Makassar dengan menggunakan rumus Product Moment. Proses perhitungan dilakukan dengan menggunakan program spss 20. Data hasil perhitungan yang berjumlah 34 butir instrumen diperoleh 29 butir instrumen yang valid. Item kuesioner yang dinyatakan valid, yaitu berjumlah 29 butir dihitung nilai koefisien reliabilitasnya dengan menggunakan rumus Alpha Cronbach. Dari hasil perhitungan tersebut diperoleh nilai koefisien reabilitas sebesar 0,927. Syarat suatu instrumen penilaian dikatakan reliabel jika koefisien korelasinya $\geq$ 0,6. Teknik Analisa Data meliputi analisis statistik desktiptif dan analisis inferensial. Analisis ini diawali dengan uji syarat analisis yaitu uji normalitas data Pengujian normalitas data hasil penelitian dengan menggunakan Kolmogrorof-Smirnov. Data dalam penelitian ini diolah menggunakan spss 20 for windows pada taraf signifikan $95 \%$ atau alfa ( $\alpha$ ) $5 \%$, diperoleh nilai sig. (2-tailed) 0,200 untuk kelas kontrol dan pada kelas eksperimen diperoleh nilai sig. (2tailed) 0,096, uji homogenitas data dilakukan dengan menyelidiki apakah kedua sampel mempunyai variansi yang sama atau tidak. Data dalam penelitian ini diolah menggunakan spss 20. menunjukkan nilai posttest pada kelompok eksperimen dan kontrol yaitu 0,757 lebih besar dari 0,05 sehingga dapat dinyatakan bahwa data penelitian berasal dari populasi yang mempunyai varian sama, dan wilayah uji hipotesis, perhitungan dilakukan menggunakan uji-t (independent Sampel t-test) dengan bantuan spss 20.0 for windows dengan taraf signifikansi $5 \%$.

\section{HASIL DAN PEMBAHASAN}

\section{Hasil}

\section{Gambaran Penerapan Metode Komidi Putar Diskusi dalam Pembelajaran IPA di SDN KIP Maccini Makassar}

Penelitian ini dilakukan di SDN KIP Maccini Makassar, yang di mulai sejak tanggal 01 April - 20 Mei 2015. Pemberian perlakuan metode komidi putar diskusi sebanyak 6 kali pertemuan selama 4 minggu. Pada pertemuan pertama minggu pertama peneliti melakukan pretest dan pada pertemuan terakhir minggu keempat peneliti melakukan posttest. Sebelum pemberian perlakuan terhadap kelompok ekperimen terlebih dahulu dilakukan wawancara terhadap guru kelas V di SDN KIP Maccini Makassar.

Hasil wawancara yang dilakukan pada guru kelas $\mathrm{V}$ diperoleh kesimpulan bahwa pembelajaran di SDN KIP Maccini Makassar menerapkan metode ceramah dan kerja kelompok. Dalam penerapan metode-metode pembelajaran, kendala yang paling sering dan umum yang dialami oleh narasumber adalah siswanya yang susah diatur ketika PBM 
berlangsung sehingga narasumber harus meninggikan volume suara bahkan berteriak untuk menenangkan siswa yang berkeliaran, sarana atau fasilitas dari sekolah yang kurang memadai atau bahkan tidak lengkap. Untuk kedepannya narasumber mengaku akan terus mengembangkan metode-metode pembelajaran sesuai dengan kondisi siswa yang diajarnya.

\section{Langkah-langkah penerapan metode komidi putar diskusi}

a. Persiapan

Pertama-tama Guru menentukan jadwal pemberian tindakan, mengecek kembali instrument yang telah disediakan serta menggandakan naskah kuesioner dan soal yang akan di bagikan kepada siswa untuk diisi. Selanjutnya merencanakan pelaksanaan tindakan yang akan dilakukan yaitu selama 3 hari dalam seminggu.

b. Kegiatan awal

Guru menyiapkan siswa untuk mengikuti pelajaran dengan mengucapkan salam dan memimpin doa serta mengabsen kehadiran siswa, menyampaikan tujuan pembelajaran apersepsi serta memotivasi siswa agar terlibat dalam proses pembelajaran. Selanjutnya guru mengajukan beberapa pertanyaan yang berhubungan dengan materi pembelajaran IPA, dan saling bercurah pendapat dengan murid.

Dari hasil observasi guru pada pelaksanaan pembelajaran menunjukkan bahwa guru telah melaksanakan beberapa indikator yang direncanakan sesuai dengan langkahlangkah metode komidi putar diskusi cukup baik. Tahap pendahuluan setiap pertemuan pada aktifitas guru mengalami peningkatan hingga diakhir pertemuan untuk indikator mempersiapkan siswa dan menyampaikan tujuan dikategorikan sangat baik sementara indikator melakukan apersepsi dikategorikan baik. Pada lembar observasi siswa, Indikator yang dilaksanakan siswa tahap pendahuluan yaitu membaca doa bersama, menyimak penyampaian guru, diakhir pertemuan menunjukkan kategori sangat baik.

c. Kegiatan inti

Disesuaikan langkah-langkah metode komidi putar diskusi yaitu sebagai berikut: (1) Tahap pengelompokan siswa, Tahap ini guru mengelompokkan siswa menjadi 2 kelompok yang heterogen, dalam setiap kelompok terdiri dari anak laki-laki dan anak perempuan perwakilan dari kategori minat sangat tinggi, tinggi, sedang, rendah dan sangat rendah. kemudian guru mengarahkan siswa duduk membentuk lingkaran dan saling berhadapan pada bangku yang telah disediakan. (2) Tahap Pembentukan lingkaran konsentris, Pada tahap ini guru bersama siswa mengatur pola pembelajaran membentuk dua lingkaran konsentri. Semua meja disingkirkan dengan kata lain dalam pembelajaran ini hanya menggunakan kursi. Guru bersama siswa mengatur letak kursi membentuk lingkaran, kursi yang berada di lingkaran dalam menghadap keluar dan kursi yang ada di lingkaran luar menghadap ke dalam sehingga posisi duduk siswa saling berhadapan. (3) Tahap Percakapan dua kelompok, Guru menjelaskan kepada siswa tentang kegiatan yang akan dilakukan yaitu melakukan percakapan (Tanya jawab) dengan teman yang ada dihadapan siswa tentang materi pembelajaran IPA. Setelah siswa saling melontarkan beberapa pertanyan dan jawaban Guru mengarahkan kelompok siswa yang berada di luar lingkaran berdiri dan mengelilingi kelompok yang berada di dalam sambil menyanyikan lagu "di sini senang di sana senang". Setelah lagu habis siswa kembali duduk di bangku dan melanjutkan percakapan dengan teman yang berada dihadapannya. (4) Tahap membuat kesimpulan, Setelah tahap ketiga dilaksanakan dan diulang beberapa sesi sesuai banyaknya waktu dan materi yang ada siswa selanjutnya ditugaskan membuat kesimpulan berdasarkan pertnyaan dan jawaban yang disampaikan temannya. Setelah semua siswa menyelesaikan rangkuman materi barulah mereka mengumpulkan rangkuman tersebut pada guru dalam bentuk laporan kegiatan.

Hasil observasi guru tahap kegiatan inti ini, pada akhir pertemuan indikator penjelasan materi, pembagian kelompok, pengarahan kegiatan diskusi kelompok menunjukkan kategori sangat baik, pada indikator memberi kesempatan bercakap, bertidak sebagai fasilitator menunjukkan kategori baik. Sementara hasil observasi siswa pada tahap inti terdiri dari indikator mendengarkan penjelasan guru, membentuk kelompok, melakukan aktvitas kelompok menunjukkan kategori sangat baik sedangkan indikator melakukan percakapan menunjukkan kategori baik.

\section{d. Tahap penutup}

Memberikan kesempatan kepada siswa untuk bertanya jika ada konsep yang belum dimengerti, dan memberikan pemantapan konsep 
agar tidak terjadi kesalahan konsep pada siswa. Pada akhir pembelajaran memberikan tes kepada siswa untuk mengevalusi pemahaman siswa sehubungan dengan materi yang telah diajarkan. Membagikan lembar tes formatif kepada seluruh siswa. Dalam pelaksanaanya, siswa menyelesaikan secara individu soal-soal yang diberikan. Selama siswa mengerjakan soal-soal yang diberikan, guru mengelilingi dan mengamati setiap aktivitas siswa. Kegiatan selanjutnya guru bersama-sama dengan siswa membahas tes formatif. Memberikan pesanpesan moral dan menutup pelajaran.

Hasil oservasi guru tahap kegiatan penutup pada akhir pertemuan indikator mengarahkan pembuatan kesimpulan, mengarahkan doa bersama menunjukkan kategori sangat baik. Sementara hasil observasi siswa tahap kegiatan penutup pada akhir pertemuan indikator mengarahkan pembuatan kesimpulan, mengarahkan doa bersama menunjukkan kategori sangat baik.

\section{Gambaran Minat Belajar IPA Siswa Kelas V SDN KIP Maccini Sebelum dan Sesudah Diberikan Metode Komidi Putar Diskusi}

Minat belajar diukur menggunakan instrumen berupa angket yang berjumlah tiga puluh enam item pernyataan. Sebelum angket diberikan pada kelas eksperimen dan kontrol terlebih dahulu divalidasi oleh ahli materi dan pembelajaran. Dalam hal ini yang menjadi validator ahli minat belajar. Selanjutnya diberikan kepada 20 responden diluar sampel penelitian dan diperoleh 29 item angket yang valid.

Tabel 4.1 gambaran kemampuan Minat siswa sebelum dan sesudah perlakuan

\begin{tabular}{|c|c|c|c|c|c|c|c|c|c|}
\hline \multicolumn{4}{|c|}{ Kelompok kontrol } & \multirow{3}{*}{ Interval } & \multirow{3}{*}{ Kategori } & \multicolumn{4}{|c|}{ Kelompok eksperimen } \\
\hline \multicolumn{2}{|c|}{ Pretest } & \multicolumn{2}{|c|}{ posttest } & & & \multicolumn{2}{|c|}{ Pretest } & \multicolumn{2}{|c|}{ Posttest } \\
\hline$F$ & $\%$ & $F$ & $\%$ & & & $f$ & $\%$ & $F$ & $\%$ \\
\hline 1 & 3.57 & 1 & 3.57 & $121-145$ & Sangat tinggi & 1 & 3.57 & 4 & 14.29 \\
\hline 2 & 7.14 & 12 & 42.86 & $98-120$ & Tinggi & 2 & 7.14 & 19 & 67.86 \\
\hline 18 & 64.29 & 15 & 53.57 & $75-97$ & Sedang & 13 & 46.43 & 3 & 10.71 \\
\hline 6 & 21.43 & 0 & 0 & $52-74$ & Rendah & 11 & 39.29 & 2 & 7.14 \\
\hline 1 & 3.57 & 0 & 0 & $29-51$ & Sangat rendah & 1 & 3.57 & 0 & 0 \\
\hline 28 & & 28 & 100 & & nlah & 28 & 100 & 28 & 100 \\
\hline
\end{tabular}

a. Gambaran Minat Belajar Siswa Sebelum Diberi Perlakuan Metode Komidi Putar Diskusi

Pada kelompok eksperimen sebelum diberikan perlakuan metode komidi putar diskusi, minat belajar IPA di SDN KIP Maccini Makassar sebanyak 1 orang siswa pada kategori sangat tinggi dengan persentase $3,57 \%$, pada kategori tinggi sebanyak 2 orang siswa dengan persentase $7,14 \%$, pada kategori sedang sebanyak 13 orang siswa dengan persentase $46,43 \%$, pada kategori rendah sebanyak 11 orang anak dengan persentase $39,29 \%$ dan pada kategori sangat rendah sebanyak 1 orang anak dengan persentase $3,57 \%$. Sedangkan pada kelompok kontrol sebelum pembelajaran (pretest) minat belajar IPA di SDN KIP Maccini
Makassar sebanyak 1 orang siswa pada kategori sangat tinggi dengan persentase $3,57 \%$, pada kategori tinggi sebanyak 2 orang siswa dengan persentase $7,14 \%$, pada kategori sedang sebanyak 18 orang siswa dengan persentase $64,29 \%$, pada kategori rendah sebanyak 6 orang anak dengan persentase $21,43 \%$ dan pada kategori sangat rendah sebanyak 1 orang anak dengan persentase $3,57 \%$.

Berdasarkan hasil analisis data nilai pretest menunjukkan bahwa kelompok eksperimen dan kontrol memiliki kemampuan awal yang tidak berbeda. Hasil pretest kedua kelas memiliki rata-rata yang kecil dan termasuk kualifikasi sedang dan rendah. Hal ini menunjukkan bahwa minat awal siswa kelompok 
eksperimen dan kelompok kontrol sebelum mengikuti pembelajaran rendah.

\section{b. Gambaran minat siswa sesudah diberi perlakuan}

Kuesioner minat belajar IPA untuk posttest sama dengan pretest. Hal itu agar tidak terjadi bias antara pretest dan posttest. Kuesioner minat belajar IPA siswa untuk posttest berjumlah 29 intem pernyataan yang memiliki rentang nilai 29-145. Skor minat siswa yang diajarkan dengan menggunakan metode komidi putar diskusi (kelompok eksperimen) diperoleh skor tertinggi adalah 133 dan terendah adalah 74. Siswa yang diajarkan dengan metode ceramah (kelas kontrol) memiliki skor tertinggi adalah 123 dan terendah adalah 84 .

Setelah diberikan perlakuan metode komidi putar diskusi, minat belajar siswa mengalami peningkatan. Pada kategori sangat tinggi terdapat 4 orang siswa dengan nilai persentase $14,29 \%$, pada kategori tinggi terdapat 19 orang siswa dengan nilai persentase $67,86 \%$, pada kategori terdapat 3 orang siswa dengan nilai persentase $10,71 \%$, pada kategori rendah terdapat 2 orang siswa dengan nilai persentase $7,14 \%$ dan pada kategori sangat rendah tidak ada siswa lagi yang berada pada kategori tersebut. Sedangkan pada kelompok kontrol Pada kategori sangat tinggi terdapat 1 orang siswa dengan nilai persentase $3,57 \%$, pada kategori tinggi terdapat 12 orang siswa dengan nilai persentase $42,86 \%$, pada kategori terdapat 15 orang siswa dengan nilai persentase $53,57 \%$, pada kategori rendah dan sangat rendah tidak ada siswa lagi yang berada pada kategori tersebut.

Hal tersebut menunjukkan bahwa kemampuan berpikir kritis siswa kelas eksperimen mengalami peningkatan yang besar jika dibandingkan dengan saat pretest. Rendahnya kemampuan berpikir kritis siswa pada kelas kontrol ini disebabkan kurang tepatnya pemilihan metode pembelajaran yang digunakan untuk minat siswa.

Hasil posttest siswa kelas eksperimen mengalami peningkatan yang lebih baik, yaitu dari kualifikasi sedang menjadi tinggi. Tingginya nilai posttest siswa terjadi akibat metode pembelajaran yang digunakan komidi putar diskusi dapat meningkatkan minat siswa dalam pembelajaran IPA. Hal itu dikarenakan terjadi pembelajaran yang menyenangkan dalam kegiatan pembelajaran.
Saat guru menggunakan metode komidi putar diskusi, siswa mengikutinya dengan baik. Pembelajaran berjalan sesuai dengan langkahlangkah metode komidi putar diskusi, yaitu: pengelompokan siswa, membentuk lingkaran, percakapan kelompok dan membuat kesimpulan.

Sebaran data kelompok eksperimen dan kelompok kontrol menunjukkan data kelompok eksperimen dengan kategori skor sangat tinggi (121-145) sebesar 14,29\% (4 siswa), kategori skor tinggi (98-120) sebesar 67,86\% (19 siswa), kategori skor sedang (75-97) dengan jumlah $10,71 \%$ (3 siswa), dan kategori skor rendah (5274) sebesar $7,14 \%$ (2 siswa) serta nilai rataratanya berada pada kategori tinggi (98-120). Dan data kelompok kontrol dengan kategori skor sangat tinggi (121-145) sebesar 3,57\% (1 siswa), kategori skor tinggi (98-120) sebesar 42,86\% (12 siswa), dan kategori skor sedang (75-97) dengan jumlah 53,57\% (15 siswa) serta nilai rata-ratanya berada pada kategori sedang (98-120). Hal ini mengindikasikan bahwa sebaran data posttest kelas eksperimen dan kontrol sangat jauh berbeda.

Berdasarkan rata-rata nilai kelas eksperimen dan kontrol diperoleh selisih sebesar 11,91 $(113,97-102,06=11,91)$, dengan kelas eksperimen di atas kelas kontrol. Perbedaan ratarata tersebut menunjukkan bahwa metode komidi putar diskusi berpengaruh untuk meningkatkan minat siswa.

Berdasarkan uarian di atas dapat disimpulkan bahwa minat belajar siswa pada kelompok eksperimen lebih tinggi daripada kelompok kontrol. Jika dilihat dari rata-rata pretest kelas kontrol dan eksperimen memiliki nilai yang hampir sama, namun hasil posttest menunjukkan kelas eksperimen lebih baik dibanding kelas kontrol. Hal ini mengindikasikan bahwa penggunaan metode komidi putar diskusi berpengaruh lebih baik untuk meningkatkan minat siswa terhadap pembelajaran IPA daripada kelas kontrol yang menggunakan metode ceramah.

\section{Pengaruh Penerapan Metode Komidi Putar Diskusi Terhadap Minat Belajar IPA di SDN KIP Maccini Makassar}

Berdasarkan hasil perhitungan uji perbedaan dua rata-rata (uji-t) dapat diketahui bahwa nilai hasil pengujian hipotesis yang disajikan bahwa secara keseluruhan bahwa $t_{\text {hitung }}$ 
$=3,338$. Rangkuman hasil perhitungan uji-t

dapat dilihat pada Tabel 4.2 sebagai berikut :

Tabel 4.2. Rangkuman hasil perhitungan uji-t

\begin{tabular}{|c|c|c|c|c|}
\hline No & $\begin{array}{c}\text { Kelompok yang } \\
\text { dibandingkan }\end{array}$ & $\mathbf{t}_{\text {hitung }}$ & $\mathbf{t}_{\text {tabel } \mathbf{0 , 0 5}}$ & Keterangan \\
\hline 1 & $\begin{array}{c}\text { Posttest } \text { Eksperimen dan } \\
\text { kontrol }\end{array}$ & 3,338 & 2,00488 & Signifikan \\
\hline
\end{tabular}

Berdasarkan Tabel 4.5 menunjukkan bahwa perhitungan uji-t menunjukkan hasil perhitungan tentang perbedaan keefektifan antara kedua metode pembelajaran secara keseluruhan bahwa $\mathrm{t}_{\text {hitung }}=3,338>\mathrm{t}_{\text {tabel }}=2,00488$ pada taraf Signifikan $\alpha=0.05$, dengan demikian $\mathrm{H}_{0}$ ditolak dan hipotesis alternatif $\mathrm{H}_{1}$ diterima. Maka minat belajar IPA antara kelompok siswa yang diberikan metode komidi putar diskusi lebih tinggi dibandingkan dengan kelompok siswa yang tidak diberikan metode komidi putar diskusi (Ceramah).

Hasil Perhitungan uji-t dapat disimpulkan bahwa terdapat perbedaan yang signifikan antara kelompok siswa yang diberikan metode komidi putar diskusi dan kelompok siswa yang tidak diberikan metode komidi putar diskusi (ceramah) terhadap minat belajar IPA. Oleh karena itu, minat belajar IPA yang diberikan metode komidi putar diskusi lebih baik secara nyata dibandingkan yang diberikan ceramah. Hal ini berarti hipotesis penelitian secara keseluruhan adalah minat belajar IPA yang diberikan metode komidi putar diskusi lebih tinggi dibandingkan dengan kelompok siswa yang diberikan ceramah.

\section{Pembahasan}

Temuan penelitian ini menunjukkan bahwa pembelajaran dengan metode komidi putar diskusi berpengaruh terhadap minat belajar IPA. Pengaruh tersebut diduga disebabkan oleh:

Pertama, siswa pada kelompok eksperimen lebih aktif daripada kelas kontrol. Keaktifan ini ditunjukkan dari kemampuan siswa di kelas ekperimen mengungkapkan pendapatnya dalam bentuk percakapan. Di sini siswa dibiasakan berbicara, seringnya anak berbicara otomatis mendapatkan perhatian bagi temannya dan bagi guru. Terjadi interaksi tanya jawab, memberi saran, menyampaikan kesimpulan, dan menyampaikan pendapat. Semua siswa mendapat kesempatan berbicara. Hal ini sesuai pendapat Slameto (2003: 180) mengatakan bahwa:

Suatu minat dapat diekspresikan melalui suatu pernyataan yang menunjukkan bahwa siswa lebih menyukai suatu hal dari pada hal lainnya, dapat pula dimanifestasikan melalui partisipasi dalam suatu aktifitas. Siswa memiliki minat terhadap suatu subyek tertentu akan cenderung untuk memberikan perhatian yang lebih besar terhadap subyek tertentu

Senada dengan pendapat diatas Ginnis (2008) mengatakan bahwa beberapa cara yang dapat diberikan kepada siswa dalam menarik minat belajarnya yaitu: berikan kesegaran dan variasi untuk mempertahankan perhatiannya, pahamilah kesenangan murid, berilah gambaran kearah mana materi yang akan dipelajari.

Penyebab kedua, anak yang tadinya hanya tau konsep setelah berdiskusi, dia dapat membangun konsep yang bersifat fakta, setelah itu mereka dapat menyelesaikan masalah dan dapat mengkomunikasikan kepada orang lain. Hal tersebut sejalan dengan teori Konstruktivisme yang didefinisikan sebagai pembelajaran yang bersifat generatif, yaitu tindakan mencipta sesuatu makna dari apa yang dipelajari. Teori kontruktivisme lebih memahami belajar sebagai kegiatan manusia membangun atau menciptakan pengetahuan dengan memberi makna pada pengetahuannya sesuai dengan pengalamannya. Pengetahuan tidak bisa ditransfer dari guru kepada orang lain, karena setiap orang mempunyai skema sendiri tentang apa yang diketahuinya. Pembentukan pengetahuan merupakan proses kognitif dimana terjadi proses asimilasi dan akomodasi untuk mencapai suatu keseimbangan sehingga terbentuk suatu skema yang baru. 
Penyebab ketiga, siswa merasa senang mengikuti pembelajaran. Hal ini diwujudkan dengan adanya langkah pembelajaran metode komidi putar diskusi berupa bermain sambil belajar. Salah satunya bernyanyi saat berputar mengelilingi lingkaran dalam. Hal ini sejalan dengan teori minat yaitu kecenderungan yang tetap untuk memperhatikan dan mengenang beberapa kegiatan. Kegiatan yang diminati seseorang, diperhatikan terus menerus yang disertai rasa senang (Slameto, 2003). Demikian pula yang dipaparkan oleh Decroly (dalam Tirtarahardja, 2010) dari penyelidikan psikologi, menetapkan bahwa anak-anak mempunyai minat spontan (sewajarnya). Minat-minat spontan itu dapat dibedakan menjadi minat terhadap diri sendiri yang meliputi dorongan mempertahankan diri, mencari makan dan minum, memelihara diri sedangkan minat terhadap mayarakat meliputi dorongan sibuk bermain-main meniru orang lain. Pendidikan dan pengajaran harus selalu dihubungkan dengan pusat-pusat minat tersebut.

Penyebab keempat, terjadi dinamika belajar antara anak yang cepat dan anak yang lambat belajar, anak yang cepat akhirnya tidak terlalu individual dan mau berbagi kepada anak yang lambat, anak yang lambat juga tidak malu lagi selalu bertanya kepada anak yang cepat sehingga semua anak terlibat dalam pembelajaran. Hal ini disebabkan oleh pembagian kelompok kecil secara heterogen pada metode komidi putar diskusi.

Berbeda halnya dalam pembelajaran yang tidak menggunakan metode komidi putar diskusi membuat siswa lebih banyak mendengar ceramah, sehingga cenderung pasif. Dalam pembelajaran ini, guru lebih banyak mendominasi kegiatan pembelajaran. Siswa masih cenderung kurang berminat dalam mengikuti pembelajaran. Selain itu, siswa lebih banyak memfokuskan pada buku pegangan siswa yang mengakibatkan kurang memahami secara mendalam substansi materinya.

Perbedaan aktifitas siswa pada kelas eksperimen ataupun kontrol diperoleh dari perbedaan cara guru dalam menyampaikan materi pembelajaran. Pada kelas yang pembelajarannya menggunakan metode komidi putar diskusi (eksperimen), siswa lebih cenderung aktif dalam proses pembelajaran, sedangkan pada kelas yang menggunakan pembelajaran konvensional (kontrol), siswa lebih cenderung pasif, baik dalam merespon pertanyaan maupun mendengarkan penjelasan yang diberikan oleh guru. Hal ini berhubungan dengan hasil tes belajar siswa yang menunjukkan adanya peningkatan setiap pertemuan yaitu pada kategori baik. Hal ini sejalan dengan pendapat Nawawi (dalam Susanto, 2012:5) yang menyatakan bahwa hasil belajar dapat diartikan sebagai suatu tingkat keberhasilan siswa dalam mempelajari materi pembelajaran disekolah yang dinyatakan dalam skor yang diperoleh dari hasil tes mengenal sejumlah materi pelajaran tertentu.

Data-data diatas dipertegas dengan adanya hasil analisis deskriptif dan inferensial yang menggambarkan adanya perbedaan yang signifikan antara kelas eksperimen dengan kelas kontrol. Pembelajaran IPA menggunakan metode Komidi putar diskusi dalam proses pembelajaran memiliki hasil yang berbeda dengan pembelajaran IPA yang menggunakan pembelajaran konvensional. Hal ini terjadi karena perlakuan yang diberikan pada kelas eksperimen dan kelas kontrol pun berbeda.

Pada kelas eksperimen yang diajar menggunakan metode komidi putar diskusi, diawali pembelajaran sesuai dengan langkahlangkah metode komidi putar diskusi. Metode pembelejaran ini efektif digunakan karena melibatkan semua siswa dalam proses pembelajaran, semua siswa mempunyai kesempatan mengungkapkan pendapatnya. Hal ini juga dikemukakan oleh Sanjaya (2012) bahwa metode adalah cara yang digunakan untuk mengimplementasikan rencana yang sudah disusun dalam kegiatan nyata agar tujuan yang telah disusun tercapai secara optimal. Sehingga metode belajar efektif diterapkan untuk meningkatkan minat belajar IPA.

Berdasarkan hasil pantauan yang dilakukan oleh peneliti pada kelompok eksperimen, guru tersebut lebih banyak memberikan materi dengan cara penjelasan dan catatan. Sehingga peserta didik merasa jenuh karena waktunya hanya dihabiskan untuk mendengarkan penjelasan guru dan mencatat materi. Hal inilah yang membuat peserta didik tersebut memiliki minat belajar yang diperoleh kelas kontrol lebih rendah dibandingkan minat belajar IPA yang diperoleh pada kelas ekperimen sehingga mempengaruhi pula hasil belajar yang diperolehnya.

Berdasarkan uraian di atas, maka metode pembelajaran komidi putar diskusi dapat diterapkan untuk meningkatkan minat belajar siswa khususnya pada kelas V SDN KIP Maccini Makassar. 


\section{SIMPULAN DAN SARAN}

Berdasarkan rumusan masalah, tujuan penelitian, dan hasil yang diperoleh sebagaimana yang telah diuraikan pada bab sebelumnya, maka pada bagian ini disajikan kesimpulan sebagai implikasi dari hasil yang diperoleh. Adapun kesimpulan sebagai berikut: Penerapan metode komidi putar diskusi yang terdiri dari tahap pengelompokan siswa, tahap membentuk 2 lingkaran konsentris, tahap percakapan dan tahap kesimpulan pada umumnya terlaksana dengan baik berdasarkan hasil dan pelaksanaannya. Minat belajar siwa dalam pembelajaran IPA di kelas V SDN KIP Maccini Makassar sebelum penerapan metode komidi putar diskusi berada pada kategori rendah dan sedang, baik pada kelompok eksperimen maupun pada kelompok kontrol. Terjadi peningkatan minat siswa pada kategori tinggi pada kelompok eksperimen setelah diberikan perlakuan metode komidi putar diskusi sedangkan kelompok kontrol pada kategori sedang. Penggunaan metode komidi putar diskusi berpengaruh terhadap minat belajar IPA siswa kelas V SDN KIP Maccini Kecamatan Makassar Kota Makassar.

Sesuai dengan kesimpulan tersebut, maka dapat diajukan beberapa saran sebagai berikut: Bagi guru diharapkan agar menerapkan metode komidi putar diskusi sebagai alternatif metode pembelajaran untuk meningkatkan minat belajar siswa. Kepala sekolah hendaknya berperan sebagai inisiator agar guru menggunakan metode komidi putar diskusi pada pembelajaran yang bersifat teoritis dan pada kelas tinggi di SD. Bagi peneliti selanjutnya, khususnya yang berkecimpung dalam pendidikan dasar, penelitian yang dilakukan dalam studi ini, hanya mengungkapkan salah satu penggunaan metode pembelajaran saja yang ada kaitannya dengan minat siswa, dan masih banyak lagi metode-metode lain yang belum diungkapkan dalam penelitian ini. Untuk itu disarankan bagi peneliti yang berminat untuk melakukan kajian lebih lanjut dan lebih mendalam.

\section{DAFTAR RUJUKAN}

Djaali, 2011, Psikologi Pendidikan, Jakarta : Bumi Aksara.

Djamarah. 2011. Psikologi Belajar. Jakarta: Rineka Cipta.
Ginnis, Paul. 2008. Trik \& Taktik Mengajar Strategi Meningkatkan Pencapaian Pengajaran di Kelas. Jakarta: Indeks.

Kemendikbud. 2011. TIMSS. Survei Internasional TIMSS, (online). (http://litbang.kemdikbud.go.id/index.ph p/survei-internasional-timss, diakses 3 Januari 2015).

Sanjaya, Wina. 2012. Strategi Pembelajaran Berorientasi Standar Proses Pendidikan. Bandung: Kencana Prenada Media Group.

Samatowa, Usman. 2011. Pembelajaran IPA di Sekolah Dasar. Jakarta: Indeks.

Sardiman. 2011. Interaksi dan Motivasi Belajar Mengajar. PT. Rajagrafindo: Jakarta

Slameto. 2010. Belajar dan Faktor-Faktor yang Mempengaruhinya. Jakarta: Rineka Cipta.

Supranto, J. 1992. Teknik Sampling Untuk Survey \& Eksperimen. Jakarta: Rineka Cipta.

Susanto, Ahmad. 2012. Teori Belajar \& Pembelajaran di Sekolah Dasar. Jakarta: Kencana Prenada Group.

Suwarno, P.J. 2009.Pendidikan Sains yang Humanistis. Yogyakarta: Kanisius.

Tirtarahardja, Umar dan Sulo, La. 2010. Pengantar Pendidikan. Jakarta: dipakai untuk kalangan sendiri. 